\title{
Plant Growth Response of Black Cohosh to Shade Levels in a High Tunnel
}

\author{
Julia Charlotte Robinson, Guochen Yang, Sanjun Gu, \\ and Zhongge (Cindy) Lu \\ College of Agriculture and Environmental Sciences, North Carolina \\ Agricultural and Technical State University, Greensboro, NC 27411
}

Additional index words. Actaea racemosa, medicinal plants, shade-tolerant plant, sustainable crop production

\begin{abstract}
Black cohosh (Actaea racemosa L.), a medicinal herb commonly used in herbal supplements for the treatment of various ailments, is a perennial herb that grows naturally under shade conditions in temperate forest regions. This project studied the growth and rhizome yield of Black cohosh under shade conditions of $0 \%, 40 \%, 60 \%$, and $\mathbf{8 0} \%$ in a high tunnel $(9.1 \mathrm{~m}$ wide $\times 29.3 \mathrm{~m}$ long) on the North Carolina Agricultural and Technical University Farm. Seed rhizomes were planted in raised beds incorporated with $9070 \mathrm{~kg} /$ acre compost and preplant fertilizer on 29 May 2016. There was one row per bed, with in-row spacing at $45.7 \mathrm{~cm}$, and one drip line per bed for irrigation. Fertigation was done weekly through the drip tapes with Multi-K 13-0-46 (27.2 kg N/acre) during the growing season. Beds were mulched after sprouting. Growth data of fully mature plants were collected on canopy width and length, total number of stems per plant, stem diameter, and length/height; and rhizome fresh and dry weight. Data were analyzed at the 0.05 level of significance. Plant canopy, stem diameter, and length/height were significantly greater in $40 \%$ shade (average, $504.7 \times 472.6 \mathrm{~mm}, 3.7 \mathrm{~mm}$, and $135.9 \mathrm{~mm}$, respectively) than in other shade conditions, with the smallest sizes in $0 \%$ shade (average, $255.8 \times 255.7 \mathrm{~mm}, 2.1 \mathrm{~mm}$, and $95.4 \mathrm{~mm}$, respectively). There were no significant differences between the $60 \%$ and $80 \%$ shade conditions in plant canopy, stem diameter, and length/height. However, the total number of stems per plant (4.9) in $0 \%$ shade was significantly more than those in other shade conditions, with the least of stems per plant (2.9) in $80 \%$ shade. Rhizome fresh and dry weight per plant were the greatest (164.6 and $48.1 \mathrm{~g}$, respectively) in $40 \%$ shade, and the least (77.8 and $22.5 \mathrm{~g}$, respectively) in $0 \%$ shade. The results indicate that optimum growing conditions for Black cohosh was in $40 \%$ shade with a Daily light integral (DLI) between 15 and $0 \mathrm{~mol} / \mathrm{m}^{2} / \mathrm{day}$, and a day- and nighttime temperature difference between 8.3 and $2.7^{\circ} \mathrm{C}$.
\end{abstract}

Before the emergence of modern medicine, humans used medicinal plants to cure human and animal ailments (Rao et al., 2004). Fighting disease has been possible throughout human history by creating new medicines from "plant materials and antibiotics from microflora" (Inoue et al., 2019, p. 2). Multiple drugs have been created using original plant source material, such as Taxol/ paclitaxel, used in the treatment of tumorous cancers, and Vinblastine, used for leukemia

Received for publication 12 Aug. 2019. Accepted for publication 18 Sept. 2019.

This research was supported by N.C. A\&T's Agricultural Research Program through U.S. Department of Agriculture/National Institute of Food and Agriculture/Evans-Allen projects NC.X280-514-130-1 and NC.X313-5-18-130-1.

We express our gratitude to Daniel M. Nonte, Interim Director of Agricultural Communications, for his review and edit of the manuscript.

J.C.R is a Graduate Student.

G.Y. is a Professor.

S.G. is an Extension Horticulture Specialist.

Z.L. is a Research Technician.

G.Y. is the corresponding author. E-mail: yangg@ ncat.edu. treatment. These drugs were derived from the Pacific yew tree and the Madagascar periwinkle, respectively, and are just a few of the examples of how medicinal plants are important in society today (Inoue et al., 2019). Within the past couple decades, there has been a reemergence of medicinal plants being used in medicine. This resurgence of plant use in medicine, as well as overharvesting of plant material by wild harvesters, has placed pressure on these plant species, leading to a decrease in plant populations and habitat destruction. The conservation of these medicinal plants is imperative to prevent extinction and to preserve and increase production. Furthermore, conservation plans need to include approaches that protect or enhance local socioeconomic benefits from cultivation of the medicinal plants and ensure safe consumption in the public health forum. The purpose of this study was to evaluate sustainable growing strategies for the at-risk medicinal plant Actaea racemosa (L.), commonly called Black cohosh, that could decrease its risk of extinction and promote cultivated growth of this economically important alternate cash crop. Sustainable strategies for Black cohosh are important, not only to prevent potential ex- tinction, but also to ensure its availability as an alternate cash crop to increase income for small-scale farmers.

Black cohosh is a valuable perennial herb native to deciduous forests in the eastern United States and Canada and is widely distributed in eastern North America from Georgia to Massachusetts (Predny et al., 2006). Commonly used as a medicinal alternative to hormone replacement therapy for women going through menopause, Black cohosh faces a current "At Risk" status as a result of overharvesting natural habitats by harvesters in the wild (Predny et al., 2006; Rao et al., 2004; Schafer, 1993). Burdette et al. (2003) reported that hormone replacement therapy has been associated with increased risk of breast cancer, coronary heart disease, stroke, and pulmonary embolism, whereas Black cohosh has been used historically in medicinal supplements to treat menopausal symptoms (Predny et al., 2006). It is important that pharmaceutical companies obtain plant material from vetted sources, decreasing the chance of harm from adulterated medicine or mislabeled plants from harvesters in the wild. Black cohosh has been cultivated successfully before, but not on a wide scale, making it important to determine which techniques work most efficiently for growers (Gardner, 2002). According to Davis and Dressler (2013), as of 2005 , "only $5 \%$ of the harvest was generated from cultivated sources," (p. 4) although organically cultivated Black cohosh has a $60 \%$ greater selling rate then wild-harvested plants. Almost all exported rhizomes (roots) are harvested in the wild, and $95 \%$ of those wild populations are exported outside of North America (Fischer et al., 2006). The "supply" from the supply and demand of Black cohosh, comes mainly from these native populations, leading to overharvesting, with no time for the Black cohosh populations to regrow. In addition, habitat destruction and theft have been noted. As of 2012, growers and harvesters in the wild were receiving an average of $\$ 11$ to $\$ 15.5 / \mathrm{kg}$ dry Black cohosh roots, wholesale prices averaged $\$ 33 / \mathrm{kg}$ dry roots, retail prices were $\$ 71$ per dry kilogram, and nursery containers ranged $\$ 3.95$ to $\$ 10.00$ per plant, according to Davis and Dressler (2013).

As a common understory plant, Black cohosh may be suitable for growth in shadehouse structures (Thomas et al., 2011). High tunnels are recommended for medicinal herbs such as Black cohosh because of its ability to mimic shade and to protect from otherwise harmful outside influences, such as inclement weather and potential pests, and are mainly used to propagate rhizomes during spring and fall (Cogger et al., 2009; Gunter, 2018). However, there is a lack of information on cultivating practices for Black cohosh because most of the plant matter used by industry comes from wild harvesting (Adam, 2002; Foster, 2013). This study investigated influences of shade conditions on growth and yield of plants in a high-tunnel setting, as well as the climatic data within each shading condition and their effect on plant growth. The goal of this research was to help farmers 
develop sustainable growing strategies for Black cohosh and allow pharmaceutical companies to obtain plant material from vetted sources. Specific goals included determining the effect of different shade conditions on Black cohosh plant growth and yield, and determining the optimal climatic conditions for plant growth. The ultimate goal was to help increase crop profitability and productivity, decrease habitat destruction and decline of the plant population caused by wild harvesters, and decrease the risk of human consumption of adulterated Black cohosh.

\section{Materials and Methods}

Seed rhizomes, obtained from Blooming Branch Farm (Burnsville, NC), were planted in raised beds incorporated with 9.07 t/acre compost, McGill Environmental System's compost with $62 \%$ organic matter content, and preplant fertilizer Weaver 17-17-17 (Winston Weaver Company, Inc., Winston Salem, NC) on 29 May 2016. In May 2017, additional rhizomes were planted as a result of a loss of plants from the previous year. A randomized complete block design was used in a high tunnel with each of the $0 \%, 40 \%, 60 \%$, and
$80 \%$ shade levels as the main plots, and Black cohosh in three 5.9-m-long plots per bed, under each shade treatment (Fig. 1). Each shade treatment had three replications with 13 plants per replication. Shadecloth, SunBlocker Premium Bulk Shadecloth (FarmTek, Dyersville, IA) at a 3.1-m width, was bought from Growers Supply. The high tunnel was also covered in a 6-mm greenhouse-grade plastic film. There was one row per bed, with in-row spacing at 45.7 $\mathrm{cm}$, and 15.2-cm drip tape, with two lines per bed. Fertigation was done weekly at a rate of $0.078 \mathrm{~kg}$ fertigation per bed per week, through the drip tape, with Multi-K 13-0-46 Fertilizer (Haifa, Israel) during the growing season. Beds were mulched with hardwood mulch at a depth of 7.6 to $10.1 \mathrm{~cm}$ after sprouting.

Data collection. Plant growth data were collected when Black cohosh reached full maturity (when flowering raceme began to form seed pods). Data included canopy width and length (both measure in millimeters), stem number, and diameter and length (both measured in millimeters). When aboveground tissue of plants died and the plants went dormant, the rhizomes were harvested and weighed for fresh and dry weight (measured in grams). Dry weight was measured

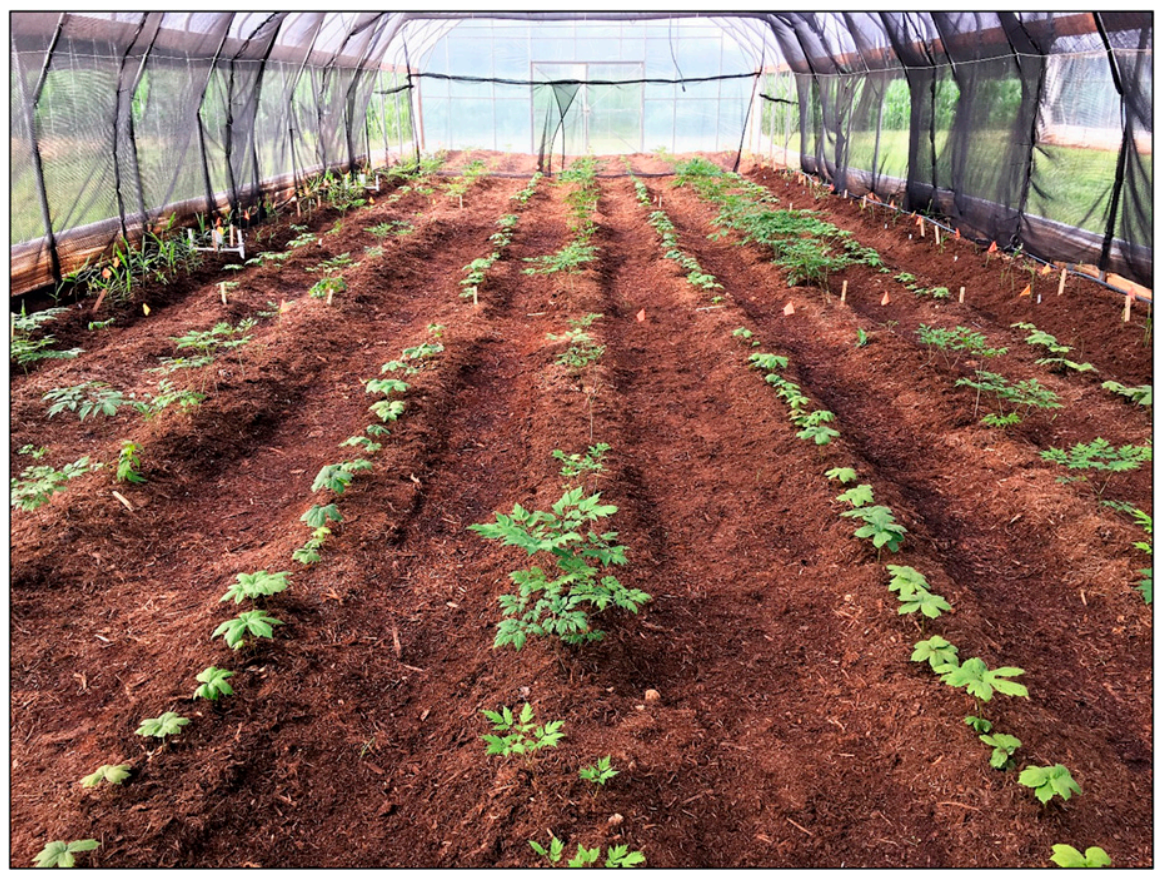

Fig. 1. Image of high tunnel with Black cohosh taken on 16 June 2017. Sun Blocker Premium shadecloth featured, with dividing shadecloth "curtain" between no shade ( $0 \%$ shade) and $40 \%, 60 \%$, and $80 \%$ shadecloth. High tunnel also had additional 6-mm greenhouse-grade plastic film covering. after sample rhizomes were placed in a Fisher Scientific Isotemp 650F Incubator Oven (Fisher Scientific, Dubuque, IA), inside open and labeled brown paper bags for air flow, at $60{ }^{\circ} \mathrm{C}$ until rhizomes were dry. All plant growth data collected were evaluated using SAS University Edition (SAS Institute, Cary, NC) and Microsoft Excel (Microsoft Corporation, Redmond, WA). Noticeable trends within each shading treatment $(0 \%, 40 \%$, $60 \%$, and $80 \%$ ) were recorded on a weekly basis, including any potential pest problems and climatic data within each shading structure. Climatic data were recorded using a WatchDog 1650 Micro Station and LightScout Quantum Light Sensor (Spectrum $^{\circledR}$ Technologies, Inc., Aurora, IL) every $30 \mathrm{~min}$ for air temperature and photosynthetically active radiation $(P A R)$ from June 2017 to Dec. 2017, the entire growing season. The recorded data were then used to determine the average monthly high and low temperatures, average monthly difference in day- and nighttime temperatures (DIF), and the DLI.

\section{Results and Discussion}

Black cohosh plant growth in different shade treatments were examined in a high tunnel (Fig. 1). As a common understory plant, it was hypothesized that increased shade would lead to an increase in rhizome yield (Quigley and Mulhall, 2002). As shown in Table 1, measurements of the stem diameter and length, canopy width and length, and rhizome fresh and dry weight were the most at $40 \%$ shade and least at $0 \%$ shade, with no significant difference between the $60 \%$ and $80 \%$ shade levels. The number of stems, however, was greatest at $0 \%$ shade and least at $80 \%$ shade, with no significant difference between the $40 \%$ and $60 \%$ and between the $40 \%$ and $80 \%$ shade levels, respectively. Similar studies growing shadetolerant plants, such as mountain laurel under increasing light, found that $40 \%$ was optimal for plant growth and that full light would have a detrimental effect on leaf coloration (Brand, 1997). Our results indicate that shading has a significant effect on the growth of Black cohosh and that shade is necessary for the plants to mature, which falls in line with previous studies of shade-tolerant plants, such as goldenseal and ginseng (Quigley and Mulhall, 2002). Exposing Black cohosh to full sun $(0 \%$ shade) also left the plants vulnerable to sun damage.

With the intent of cultivating rhizomes for farmers, our data indicate that $40 \%$ shade is

Table 1. Black cohosh mean growth data per shade treatment $(0 \%, 40 \%, 60 \%$, and $80 \%$ shade) in a high tunnel covered with 6-mm greenhouse-grade plastic film.

\begin{tabular}{|c|c|c|c|c|c|c|c|}
\hline $\begin{array}{l}\text { Shade } \\
\text { percentage }\end{array}$ & $\begin{array}{c}\text { Canopy } \\
\text { width }(\mathrm{mm})\end{array}$ & $\begin{array}{c}\text { Canopy } \\
\text { length }(\mathrm{mm})\end{array}$ & Stem no. & $\begin{array}{c}\text { Stem } \\
\operatorname{diam}(\mathrm{mm})\end{array}$ & $\begin{array}{c}\text { Stem } \\
\text { length }(\mathrm{mm})\end{array}$ & $\begin{array}{c}\text { Rhizome } \\
\text { fresh wt (g) }\end{array}$ & $\begin{array}{l}\text { Rhizome } \\
\text { dry wt (g) }\end{array}$ \\
\hline 0 & $255.8 \pm 113.1 \mathrm{a}$ & $255.7 \pm 117.9 \mathrm{a}$ & $4.9 \pm 2.6 \mathrm{a}$ & $2.1 \pm 0.91 \mathrm{a}$ & $94.5 \pm 55.2 \mathrm{a}$ & $77.8 \pm 73.6 \mathrm{a}$ & $22.5 \pm 21.6 \mathrm{a}$ \\
\hline 40 & $504.7 \pm 240.1 b$ & $472.6 \pm 193.1 \mathrm{~b}$ & $3.3 \pm 1.3 \mathrm{bc}$ & $3.7 \pm 5.0 \mathrm{~b}$ & $135.9 \pm 53.0 \mathrm{~b}$ & $164.6 \pm 88.2 b$ & $48.1 \pm 26.5 b$ \\
\hline 60 & $416.6 \pm 208.4 c$ & $467.6 \pm 235.5 \mathrm{bc}$ & $3.4 \pm 1.9 \mathrm{bc}$ & $2.8 \pm 1.4 \mathrm{c}$ & $129.3 \pm 63.7 b$ & $129.5 \pm 88.2 \mathrm{ab}$ & $33.4 \pm 26.5 \mathrm{ab}$ \\
\hline 80 & $428.6 \pm 190.4 \mathrm{c}$ & $420.2 \pm 197.3 \mathrm{c}$ & $3.0 \pm 1.3 \mathrm{c}$ & $2.7 \pm 1.1 \mathrm{c}$ & $125.0 \pm 56.4 \mathrm{~b}$ & $91.3 \pm 84.1 \mathrm{ab}$ & $32.0 \pm 38.6 \mathrm{al}$ \\
\hline
\end{tabular}

Mean separation (in columns) by Fisher's least significant difference test at $P \leq 0.5$ (lowercase letters). Standard deviation indicated by \pm in parenthesis. Means were calculated by adding the total sum of data under each shade and dividing by the total number of plants per shade treatment ( 39 total plants per shade treatment). 


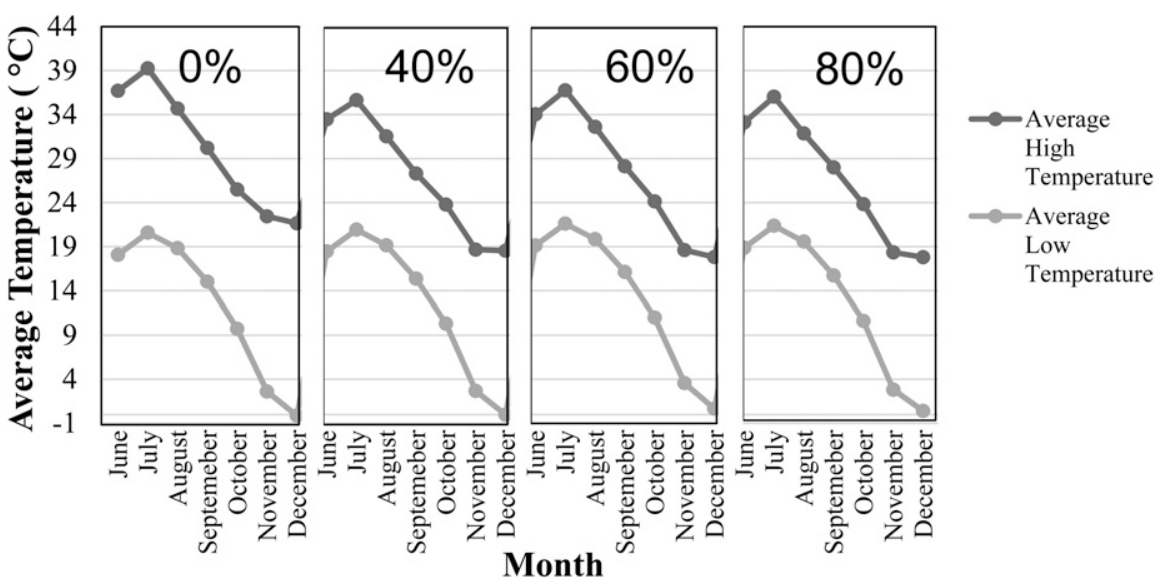

Fig. 2. The average monthly high and low temperatures $\left({ }^{\circ} \mathrm{C}\right)$ inside the high tunnel during the Black cohosh growing season (June-Dec. 2017).

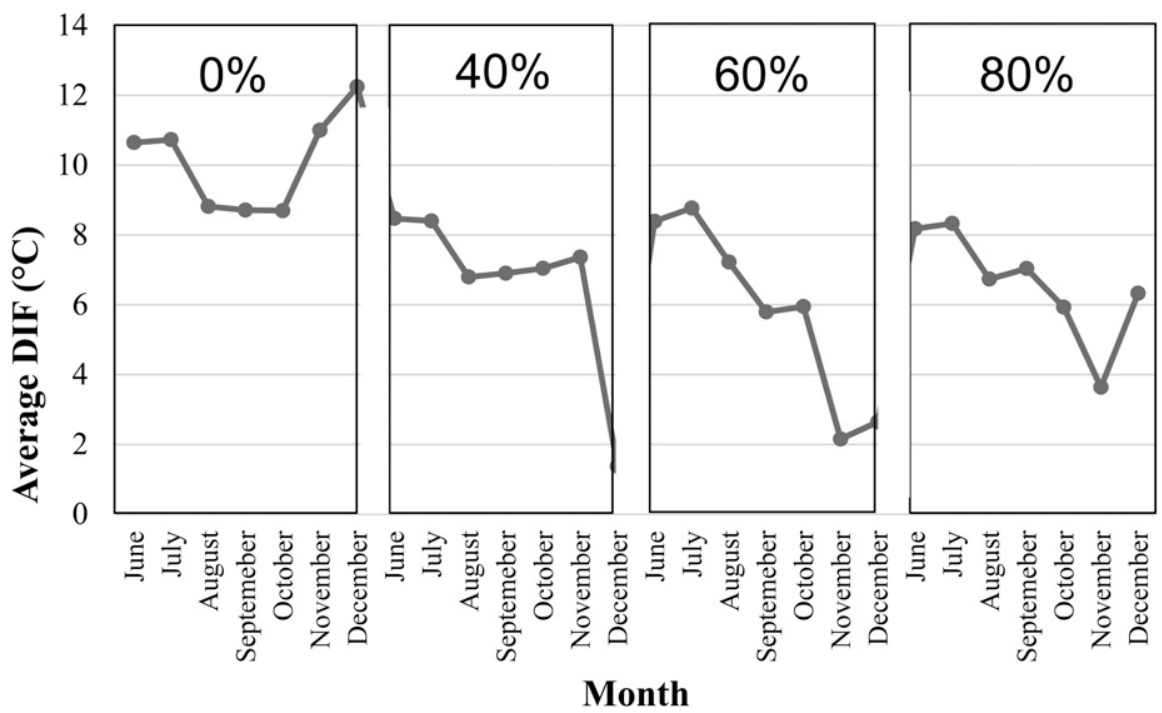

Fig. 3. The average monthly difference in day- and nighttime temperatures (DIF) inside the high tunnel during the Black cohosh growing season (June-Dec. 2017).

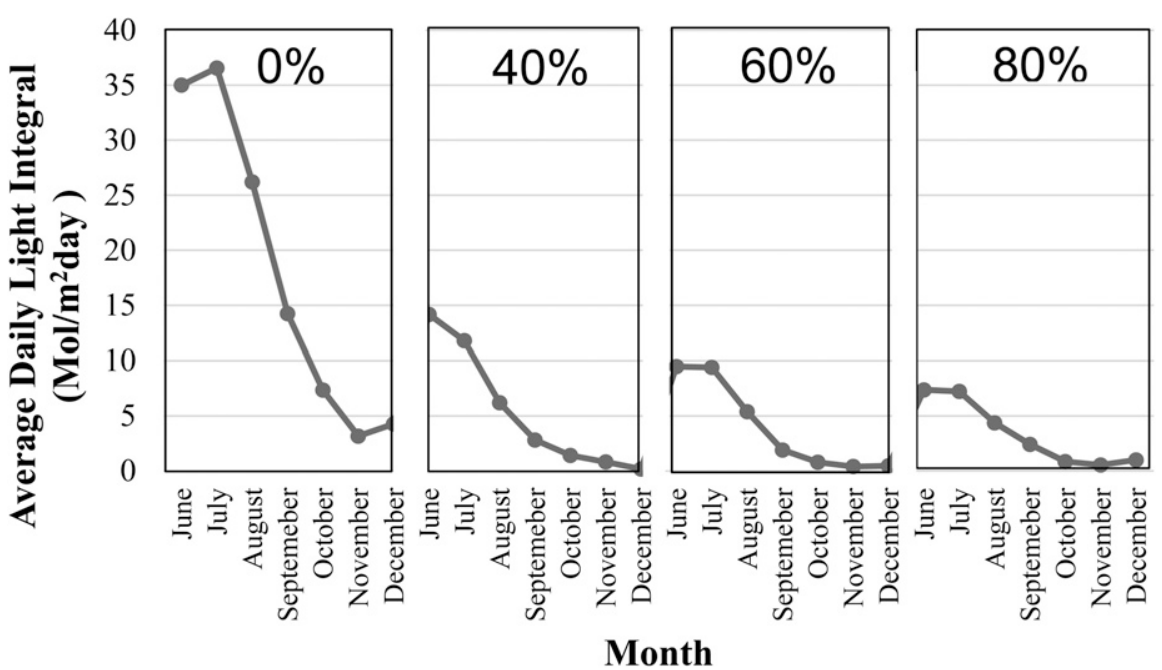

Fig. 4. The monthly average daily light integral inside the high tunnel during the Black cohosh growing season (June-Dec. 2017). ideal for rhizome production and plant growth, which is supported by a study done at the University of Missouri's Southwest Research Center, where the effect of $0 \%$, $40 \%$, and $80 \%$ shade on Black cohosh rhizome growth was studied, and data from that study suggest there is an informal increase in mortality for plants grown in $0 \%$ shade (Thomas et al., 2011). Plants in our study, however, were a mixture of new rhizomes and 1-year-old plants grown previously in a high tunnel, with no clarification of where new plants occurred and where 1-year-old plants were located. Although this difference in plant age could have skewed data, the significant changes in plant growth analyzed from $0 \%$ to $40 \%$ shade indicate at least an informal certainty that $40 \%$ shade is the most effective cultivating practice.

Plant growth data were supported further with climate data in the high tunnel-mainly, the monthly average high and low temperatures, DLI, and DIF per shade level during the growing season. The average monthly high and low temperatures within the high tunnel did not change significantly from $40 \%$ to $80 \%$ shade. The $0 \%$ shade level did increase the average high temperatures from June through August and November through December compared with that of the other shading levels. The average monthly low temperatures did not significantly change across all shade levels (Fig. 2), which created a wider gap between the highest and lowest average temperatures, from June through August and November through December for the $0 \%$ shade level. The DIF was evaluated for each shade level within the high tunnel structure (Fig. 3). During the growing season, there was a positive DIF for the duration, where daytime temperatures were higher than nighttime temperatures. Under $0 \%$ shade there was the least amount of change in DIF during the growing season, averaging from a little more than 8 to $11^{\circ} \mathrm{C}$, with a greater difference occurring during June and July as well as November and December. In contrast, in $40 \%$ shade there was a marked decrease in DIF as the growing season continued, with the greatest DIF occurring during June and July at $8.3{ }^{\circ} \mathrm{C}$, and then decreasing steadily until December to less than $2.7{ }^{\circ} \mathrm{C}$. Likewise, the $60 \%$ and $80 \%$ shade levels decreased the DIF during the growing season from a little more than $8.3{ }^{\circ} \mathrm{C}$ to less than $2.7^{\circ} \mathrm{C}$, before increasing during December.

The DLI is the amount of PAR (wavelength, 400-700 nm) each day as a function of light intensity (Torres and Lopez, 2018). During our study, the DLI decreased under all shade levels as the growing season progressed from June through December. The DLI that was measured also indicated a drastic difference in the $0 \%$ shade level, where the average DLI decreased from 35 to less than $5 \mathrm{~mol} / \mathrm{m}^{2} / \mathrm{d}$, whereas the $40 \%$ shade level decreased from 15 to $0 \mathrm{~mol} / \mathrm{m}^{2} / \mathrm{d}$; in $60 \%$ and $80 \%$ shade, the average DLI decreased from 10 to a little more than $0 \mathrm{~mol} /$ $\mathrm{m}^{2} / \mathrm{d}$ (Fig. 4). Plants grown under low DLI 
conditions usually demonstrate limited growth, however, in the case of Black cohosh, this is not completely true, with plant growth and yield increasing in $40 \%$ shade. Faust et al. (2005) reported that "categorizing individual species (begonia, impatiens, marigold, petunia, vinca, and zinnia) responses to DLI is useful for commercial producers," (p. 648) because of the significant effect of DLI on either flowering or total biomass of the plants. This is apparent when looking at the data in Table 1, which shows plants had a significant reduction in growth and development when exposed to greater levels of DLI. Plants demonstrated optimum growth at the $40 \%$ shade level and the least amount of growth at the $0 \%$ shade level. However, lower levels of DLI, such as those that occur in $60 \%$ and $80 \%$ shade, demonstrate a decrease in stem diameter as well as rhizome yield (rhizome fresh and dry weights). Similarly, the DIF measurement in Fig. 3 was greatest at $0 \%$ shading, which would normally indicate that plant elongation and growth would be greater in this shade level. However, in the case of Black cohosh, it was reduced significantly. This differs from other studies, such as that by Yang et al. (2016), where it was determined that positive DIFs increased root dry weight significantly. Currey and Lopez (2015) that determined that DLI has a linear trend where root biomass increased as DLI increases.

In summary, Black cohosh grown in $40 \%$ shade had the most increased growth for canopy size, stem diameter, and length, as well as rhizome fresh and dry weight among the shade levels studied. Stem number increased significantly in $0 \%$ shade; however, there was also noticeable sun damage to leaves in $0 \%$ shade. There was no significant change in stem length and number of stems as shade level increased from $40 \%$ to $80 \%$ shade, there was a decrease in stem diameter and rhizome fresh and dry weights from $40 \%$ to $80 \%$ shade, and there was a significant decrease in canopy size between $40 \%$ and $80 \%$ shade. There was no significant differ- ence in plant growth from $60 \%$ to $80 \%$ shade. Our data indicate that optimum growing conditions for Black cohosh should be in $40 \%$ shade, with a DLI between 0 and 15 $\mathrm{mol} / \mathrm{m}^{2} / \mathrm{d}$ and a DIF between 2.7 and $8.3{ }^{\circ} \mathrm{C}$.

\section{Literature Cited}

Adam, K. 2002. Ginseng, goldenseal, and other native roots: Horticultural technical note. In: R. Earles (ed.). Appropriate technology transfer for rural areas. 13 June 2019. <https://attra.ncat.org/ attra-pub/download.php?id=40>.

Brand, M.H. 1997. Shade influences plant growth, leaf color, and chlorophyll content of Kalmia latifola L. cultivars. HortScience 32:206-208.

Burdette, J.E., J. Liu, S.N. Chen, D.S. Fabricant, C.E. Piersen, E.L. Barker, J.M. Pezzuto, A. Mesecar, R.B. Van Breemen, N.R. Farnsworth, and J.L. Bolton. 2003. Black cohosh acts as a mixed competitive ligand and partial agonist of the serotonin receptor. J. Agr. Food Chem. 51(19):5661-5670.

Cogger, T.L., W.I. Ashland, and D. Burgdorf. 2009. Community garden guide season extension high tunnel. Natural Resources Conservation Service 13 June 2019. <https://www.nrcs usda.gov/Internet/FSE_PLANTMATERIALS/ publications/mipmcar9778.pdf>.

Currey, C.J. and R.G. Lopez. 2015. Biomass accumulation and allocation, photosynthesis, and carbohydrate status of new guinea impatiens, geranium, and petunia cuttings are affected by photosynthetic daily light integral during root development. J. Amer. Soc. Hort. Sci. 140:542-549.

Davis, J. and A. Dressler. 2013. Black Cohosh (Actaed racemosa L.). Mountain Hort. Crops Res. \& Ext. Center 1-7. 10 June 2019. <www.extension.org forest_farming $>$. Revision of two manuscripts. 10 June 2019. <www.ncmedicinalsofnc.org >, <www. ces.ncsu.edu/depts/hort/hil/pdf/hil-135.pdf $>$.

Faust, J.E., V. Holcombe, N.C. Rajapakse, and D.R. Layne. 2005. The effect of daily light integral on bedding plant growth and flowering. HortScience 40:645-649.

Fischer, S., M. Berti, R. Wilckens, and A.D. Pozo. 2006. Development of vegetative propagation for Actaea racemosa Nutt. Ind. Crops Prod. 24(3):244-252.

Foster, S. 2013. Exploring the peripatetic maze of Black cohosh adulteration: A review of the nomenclature, distribution, chemistry, market status, analytical methods, and safety. HerbalGram 98:32-51.

Gardner, Z. 2002. Cultivation and marketing of woodland medicinal plants: Spring 2002 special supplement on agroforestry. Northeast Organic Farming Association. 13 June 2019.<http://www. nofa.org/tnf/sp02/supplement/medicinalni.pdf $>$.

Gunter, C. 2018. In: K.A. Moore and L.K. Bradley (eds.). North Carolina extension gardener handbook. North Carolina State Extension, College of Agri and Life Science, North Carolina State University, Raleigh, NC.

Inoue, M., S. Hayashi, and L.E. Craker. 2019. Role of medicinal and aromatic plants: Past, present, and future, p. 1-13. In: A. Perveen and A. Al-Taweel (eds.). Pharmacognosy. IntechOpen London, UK.

Predny, M.L., P. DeAngelis, and J. Chamberlain. 2006. Black cohosh (Actaea racemosa): An annotated bibliography. GEN. TECH. Rep. SRS-97. Southern Research Station 1-99. 12 June 2019. <https://www.srs.fs.usda.gov/pubs/ gtr/gtr_srs097.pdf>

Quigley, M.F. and S. Mulhall. 2002. Effects of variable shading in a greenhouse study on rhizome weight, root length, and bud proliferation in goldenseal. HortTechnology 12:717720 .

Rao, M., M. Palada, and B. Becker. 2004. Medicinal and aromatic plants in agroforestry systems. Agrofor. Syst. 61-62(1-3):107-122.

Schafer, P.D. 1993. A manual of cherokee herbal remedies: History, information, identification, medicinal healing. Indiana State University, Terre Haute, IN, PhD Diss.

Thomas, A.L., W.L. Applequist, G.E. Rottinghaus, and J.S. Miller. 2011. Black cohosh rhizome and phytochemical production in response to shading, spacing, and age. Acta Hort. 925:175183.

Torres, A.P. and R.G. Lopez. 2018. Commercial greenhouse production: Measuring daily light integral in a greenhouse. Purdue Department of Horticulture and Landscape Architecture. 13 June 2019. <https://www.extension.purdue. edu/extmedia/ho/ho-238-w.pdf>.

Yang, Z., Y. Li, P. Li, F. Zhang, and B.W. Thomas. 2016. Effect of difference between day and night temperature on tomato (Lycopersicom esculentum Mill.) root activity and low molecular weight organic acid secretion. Soil Sci. Plant Nutr. 62(5-6):423-431. 